\title{
Fabrication and Characterisation of Porous Coatings Enriched with Copper on CP Titanium Grade 2 under Plasma Electrolytic Oxidation
}

\author{
Krzysztof ROKOSZ, Tadeusz HRYNIEWICZ, Sofia GAIASCHI, Patrick CHAPON, Steinar RAAEN, Łukasz DUDEK, Winfried MALORNY
}

\begin{abstract}
In the present paper, coatings obtained on CP Titanium Grade 2 samples by Plasma Electrolytic Oxidation (PEO) in electrolyte containing concentrated phosphoric acid $\mathrm{H}_{3} \mathrm{PO}_{4}$ with copper nitrate $\mathrm{Cu}\left(\mathrm{NO}_{3}\right)_{2} \cdot 3 \mathrm{H}_{2} \mathrm{O}$, are studied with Scanning Electron Microscopy (SEM), Energy Dispersive X-Ray Spectroscopy (EDS), X-Ray Photoelectron Spectroscopy (XPS) and Glow Discharge Optical Emission Spectroscopy (GDOES). A three-layer model is proposed on the basis of GDOES depth profile signals and their first and second derivatives. It was found that the time of Plasma Electrolytic Oxidation process has an influence on the chemical composition and the thickness of the obtained porous coatings. The longer time the PEO treatment is applied, the thinner porous coatings are obtained and the lowest amounts of copper, phosphorus and oxygen inside them are found. The proposed model of PEO coatings consists of three layers, i.e. the top one "A", having a thickness corresponding to the sputtering time in GDOES of about $100 \mathrm{~s}$; the operating conditions applied provide very porous and contaminated by organic substances layer down to about $50 \mathrm{~s}$ by sputtering time; the semi-porous sub-layer named "B" has a thickness that depends on the PEO treatment time. The sub-layer "B" of PEO coating is the thickest after one-minute PEO treatment and it decreases with increasing the treatment time. The PEO coating thickness also decreases after each successive PEO processing. The last layer (from the top surface), is the transition sub-layer named "C", and it has a thickness corresponding to a sputtering time equaling $450 \mathrm{~s}$.
\end{abstract}

Keywords: copper(II) nitrate(V) trihydrate; GDOES depth profiles and derivatives; Plasma Electrolytic Oxidation (PEO); SEM/EDS; three-layer model; titanium

\section{INTRODUCTION}

Contemporary surface technology is frequently realized under electrochemical processing, effective with oxide layers of nanometric thickness or porous compounded layers of micrometric thickness. In view of obtaining nano-layers, the standard electrochemical polishing (EP) method [1-5], electropolishing in magnetic field (MEP) [6-12] or high-current density electropolishing (HDEP) [14, 15], or High-Voltage Electropolishing (HVEP) [16], are used. Micro-layers with micro- and nanopores may be obtained by Plasma Electrolytic Oxidation (PEO), which is also described in literature as Micro Arc Oxidation (MAO) on metals, e.g. titanium [17-19], niobium [20], tantalum [21, 22], zirconium [23], and alloys, such as Ti6Al4V [24], NiTi [25], and TNZ (Ti-NbZr) [26], Ti-Nb-Zr-Sn [27], Ti-3Zr-2Sn-3Mo-25Nb [28]. In the present work, results of porous PEO coatings enriched with bactericidal copper [29], similar to those ones presented in references [30-32], obtained on titanium, treated by $\mathrm{PEO}$ in electrolyte containing $\mathrm{H}_{3} \mathrm{PO}_{4}$ with $\mathrm{Cu}\left(\mathrm{NO}_{3}\right)_{2}$, are displayed. The previous works of the Authors [25, 30, 31] with XPS results have shown clearly that in top layer of $10 \mathrm{~nm}$ of the PEO coating, titanium is on the fourth stage of oxidation $\left(\mathrm{Ti}^{4+}\right)$ while copper is on the first and second stages of oxidation $\left(\mathrm{Cu}^{+}\right.$and $\left.\mathrm{Cu}^{2+}\right)$. The detected phosphorus and oxygen indicated that the obtained structure of the coating is dominated by phosphates of titanium and copper. The present work is to answer the question whether the processing time affects the composition and thickness of the PEO coating obtained on titanium. Therefore, the main issue of the presented results is to show the dependence of the thickness and composition of the porous coatings with reference to the treatment time and aging of electrolyte used. The surface characterizations of the porous coatings obtained by PEO treatment were mainly performed by SEM with EDS and by GDEOS. These two techniques are also used in the present paper to describe the chemical composition of these coatings.

\section{METHODS}

CP Titanium Grade 2 samples under Plasma Electrolytic Oxidation (PEO)/Micro Arc Oxidation (MAO) were treated for the study. They were in the form of rectangular specimens of size $30 \times 10 \mathrm{~mm}$ cut off from a metal sheet $2 \mathrm{~mm}$ thick. In order to maintain normalized starting conditions of the specimens, surface samples were ground by abrasive mechanical treatment using 240 grit size.

The PEO during the preliminary studies was performed at the average voltage of $450 \pm 46 \mathrm{~V}$ with pulsation at frequency of $300 \mathrm{~Hz}$ during 3 minutes of treatment by using the three-phase transformer with six diodes of Greatz Bridge as well as at $450 \mathrm{~V}_{\mathrm{DC}}$ voltage without any pulsation with the use of commercial PWR 1600H, Multi Range DC Power Supply 1600W, 0$650 \mathrm{~V} / 0-8 \mathrm{~A}$.

The electrolyte was composed of orthophosphoric acid $\mathrm{H}_{3} \mathrm{PO}_{4}(85 \% \mathrm{w} / \mathrm{w})$ and copper (II) nitrate (V) trihydrate $\mathrm{Cu}\left(\mathrm{NO}_{3}\right)_{2} \cdot 3 \mathrm{H}_{2} \mathrm{O}$. During the preliminary studies (experiments performed on homemade power supply with three phase transformer and Greatz Brige) for each run, the electrolyte volume was equal to $0.25 \mathrm{~L}$, while for main research, which was done by using the commercial power supply, in the cell containing $0.5 \mathrm{~L}$ volume of electrolyte. The SEM, EDS, XPS, GDOES, and roughness measurement instruments with operating conditions were described in our previous papers $[26,27]$. Characterization of porous surfaces was done with/using non-contact methods [33, 34]. According to the EN ISO 4287:1999 (Geometrical product specifications (GPS)-surface texture: profile method-terms, definitions and surface texture parameters) and DIN 4768 (Determination of values of surface roughness parameters $R a, R z, R_{\max }$ using electrical contact (stylus) instruments; concepts and measuring conditions) standards, the following roughness parameters have been measured: arithmetic average of the absolute values of the profile heights over the evaluation length/roughness average $(R a)$, average peak-to-valley 
height when there are five sampling lengths $\left(R z^{\mathrm{DIN}}\right)$, tenpoint height of irregularities $R z^{\mathrm{ISO}}$ ), root mean square average of the profile heights $(R q)$, maximum height of the profile/vertical distance between the highest and the lowest points of the profile $(R t)$, mean spacing of the profile irregularities $(R S m)$, the ratio of the developed profile length to the evaluation length $\left(l_{0}\right)$ and profile peak density (D).

\section{RESULTS AND DISCUSSION}

In Fig. 1 and Tab. 1, the SEM pictures (Fig. 1) and EDS spectrum analysis (Table1) of porous coating formed on titanium after PEO process at voltage of $450 \mathrm{~V}$ after 1 minute in $600 \mathrm{~g}$ (preliminary studies) and $500 \mathrm{~g}$ (main studies) of copper nitrate $\mathrm{Cu}\left(\mathrm{NO}_{3}\right)_{2} \cdot 3 \mathrm{H}_{2} \mathrm{O}$ in $1 \mathrm{~L} \mathrm{H}_{3} \mathrm{PO}_{4}$ electrolyte, with $500 \times$ and $6000 \times$ magnifications, are presented. The obtained surface is porous with a copper-tophosphorus ratio $(\mathrm{Cu} / \mathrm{P})$ equaling 0.26 by weight concentration and 0.12 by atomic concentration, as shown in Fig. 2. The pores are partly opened on the top of the PEO coating and closed inside the obtained coating.

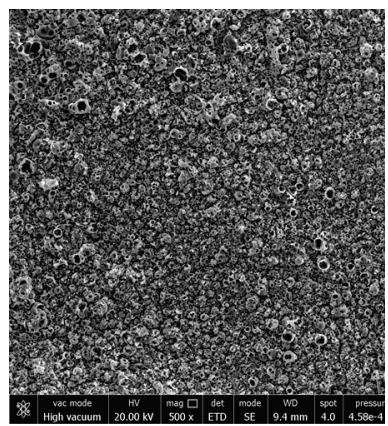

(a)

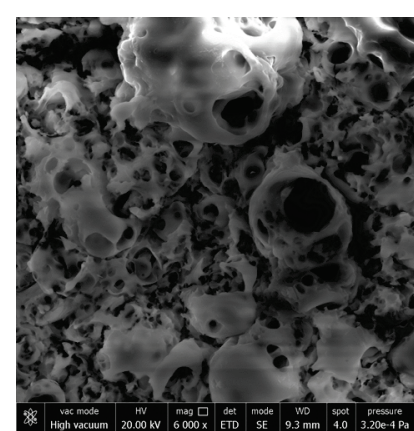

(b)
Figure 1 SEM images of coating formed on Titanium after $\mathrm{PEO}$ process at voltage of $450 \mathrm{~V}$ after 1 min in $600 \mathrm{~g} / \mathrm{L}$ of $\mathrm{Cu}\left(\mathrm{NO}_{3}\right)_{2} \cdot 3 \mathrm{H}_{2} \mathrm{O}$ in $\mathrm{H}_{3} \mathrm{PO}_{4}$ electrolyte. Magnifications: $500 \times(\mathrm{a})$ and $5000 \times(\mathrm{b})$

Table 1 Quantitative results of weight and atomic concentrations of selected elements and $\mathrm{Cu} / \mathrm{P}$ ratio based on the EDS of surface presented in Fig. 1

\begin{tabular}{|c|c|c|}
\hline Elementlines & $\mathrm{wt} \%$ & $\mathrm{at} \%$ \\
\hline $\mathrm{P} \mathrm{K}$ & 36.9 & 48.5 \\
\hline $\mathrm{Ti} \mathrm{K}$ & 53.6 & 45.5 \\
\hline $\mathrm{Cu} \mathrm{K}$ & 9.5 & 6.0 \\
\hline $\mathrm{Cu} / \mathrm{P}$ & $\mathbf{0 . 2 6}$ & $\mathbf{0 . 1 2}$ \\
\hline
\end{tabular}

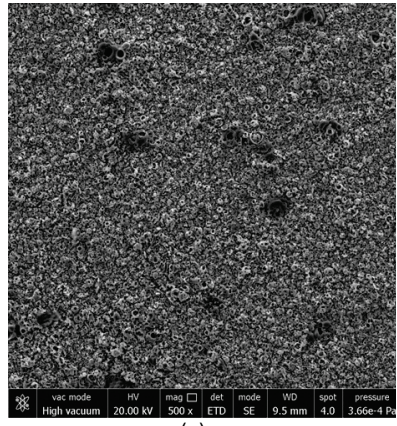

(a)

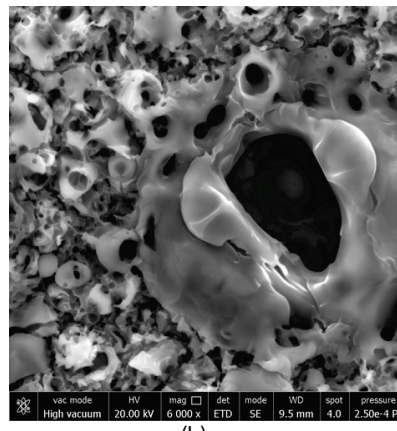

(b)
Figure 2 SEM images of coating formed on titanium after $\mathrm{PEO}$ process at voltage of $450 \mathrm{~V}$ after $3 \mathrm{~min}$; in $600 \mathrm{~g} / \mathrm{L}$ of $\mathrm{Cu}\left(\mathrm{NO}_{3}\right)_{2} \cdot 3 \mathrm{H}_{2} \mathrm{O}$ in $\mathrm{H}_{3} \mathrm{PO}_{4}$ electrolyte. Magnifications: $500 \times(\mathrm{a})$ and $6000 \times(\mathrm{b})$

In Fig. 2 and Tab. 2, the SEM image and quantitative results of EDS of porous coating formed on Titanium after PEO process at voltage of $450 \mathrm{~V}$ after 3 minutes in $600 \mathrm{~g} / \mathrm{L}$ of $\mathrm{Cu}\left(\mathrm{NO}_{3}\right)_{2}$ in $1 \mathrm{~L} \mathrm{H}_{3} \mathrm{PO}_{4}$ electrolyte with $500 \times$ and $6000 \times$ magnifications, are presented. The obtained surface is porous and with copper-to-phosphorus ratio $(\mathrm{Cu} / \mathrm{P})$ equalling to 0.26 by weight concentration and 0.12 by atomic concentration.

Table 2 Quantitative results of weight and atomic concentrations of selected elements and $\mathrm{Cu} / \mathrm{P}$ ratio based on the EDS of surface presented in Fig. 2

\begin{tabular}{|c|c|c|}
\hline Elementlines & $\mathrm{wt}^{\%} \%$ & $\mathrm{at} \%$ \\
\hline $\mathrm{P} \mathrm{K}$ & 38.4 & 50.1 \\
\hline $\mathrm{Ti} \mathrm{K}$ & 51.2 & 43.3 \\
\hline $\mathrm{Cu} \mathrm{K}$ & 10.4 & 6.6 \\
\hline $\mathrm{Cu} / \mathrm{P}$ & $\mathbf{0 . 2 7}$ & $\mathbf{0 . 1 3}$ \\
\hline
\end{tabular}

In Fig. 3 and Tab. 3, the SEM image and quantitative results of EDS of porous coating formed on Titanium after PEO process at voltage of $450 \mathrm{~V}$ after 5 minutes in $600 \mathrm{~g} / \mathrm{L}$ of $\mathrm{Cu}\left(\mathrm{NO}_{3}\right)_{2}$ in $1 \mathrm{~L} \mathrm{H}_{3} \mathrm{PO}_{4}$ electrolyte with $500 \times$ and $6000 \times$ magnifications, are presented. The obtained surface is porous with mostly closed pores and with copper-tophosphorus ratio $(\mathrm{Cu} / \mathrm{P})$ equalling 0.14 by weight concentration and 0.07 by atomic concentration. The amount of copper inside the PEO coating after 5 minutes of oxidization is about twice smaller than the one found after one- or three-minute PEO treatment, i.e. in fact it equals $4.8 \mathrm{wt} \%(3.1 \mathrm{at} \%)$.

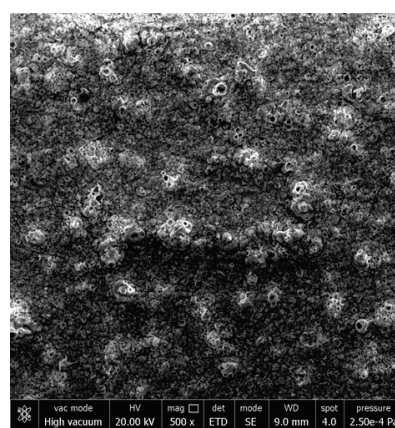

(a)

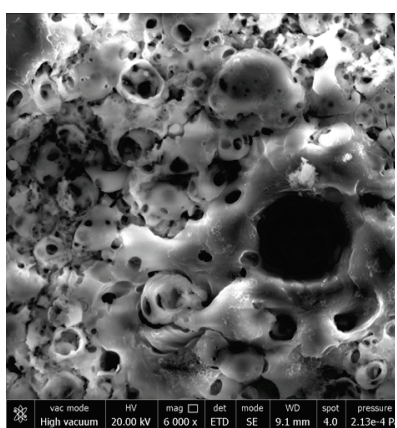

(b)
Figure 3 SEM images of coating formed on Titanium after PEO process at voltage of $450 \mathrm{~V}$ after $5 \mathrm{~min}$; in $600 \mathrm{~g} / \mathrm{L}$ of $\mathrm{Cu}\left(\mathrm{NO}_{3}\right)_{2} \cdot 3 \mathrm{H}_{2} \mathrm{O}$ in $\mathrm{H}_{3} \mathrm{PO}_{4}$ electrolyte. Magnifications: $500 \times(\mathrm{a})$ and $6000 \times(\mathrm{b})$

Table 3 Quantitative results of weight and atomic concentrations of selected elements and Cu/P ratio based on the EDS of surface presented in Fig. 3

\begin{tabular}{|c|c|c|}
\hline Elementlines & $\mathrm{wt} \%$ & $\mathrm{at} \%$ \\
\hline $\mathrm{P} \mathrm{K}$ & 33.2 & 44.0 \\
\hline $\mathrm{Ti} \mathrm{K}$ & 62.0 & 52.9 \\
\hline $\mathrm{Cu} \mathrm{K}$ & 4.8 & 3.1 \\
\hline $\mathrm{Cu} / \mathrm{P}$ & $\mathbf{0 . 1 4}$ & $\mathbf{0 . 0 7}$ \\
\hline
\end{tabular}

In Fig. 4, the GDOES spectra of copper (325 nm), phosphorus (178 nm), oxygen (130 nm), hydrogen (122 $\mathrm{nm})$, nitrogen $(149 \mathrm{~nm})$ and titanium $(365 \mathrm{~nm})$, are presented, respectively. The results displayed in that Figure demonstrate that there is a high influence of the plasma electrolytic oxidation time on the chemical composition of PEO coating as a function of depth.

The longer time of PEO treatment, the thinner is the porous coating and the lower are the amounts of copper, phosphorus and oxygen inside it. To compare all the spectra, Authors have used the first and second derivatives of the GD signals (Fig. 4) and propose a model presenting sub-layers (Fig. 5), for which thicknesses are dependent on the PEO treatment time. Based on data presented in Fig. 4, it is possible to conclude that the top sub-layers "A", which are presented in Fig. 5a, have thicknesses corresponding to a sputtering time of about $100 \mathrm{~s}$. They are very porous and 
contaminated by organic substances down to a sputtering time of about $50 \mathrm{~s}$ because of the contact with surrounding environment/air and with cleaning liquids (alcohols). The thickness of the second, semi-porous sub-layer "B", which is displayed in Fig. 5b, is dependent on the PEO treatment time, i.e. the thickest one is gained after one-minute of PEO treatment and it gradually decreases with increasing processing time.
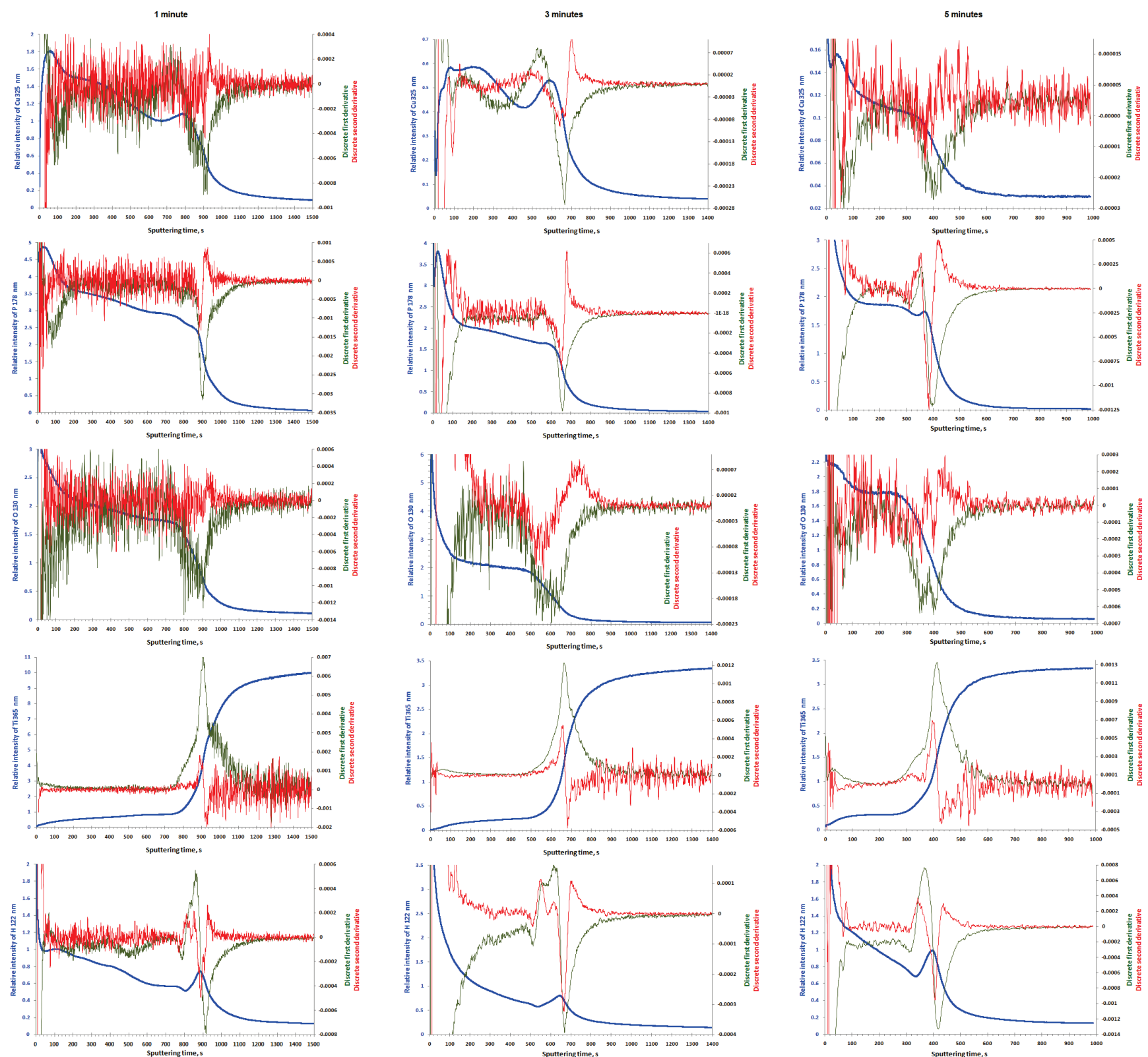

Figure 4 GDOES signals with the first and second derivatives of copper, phosphorus, oxygen, titanium and hydrogen of coatings formed on titanium; influence of PEO oxidation time on PEO coating formation

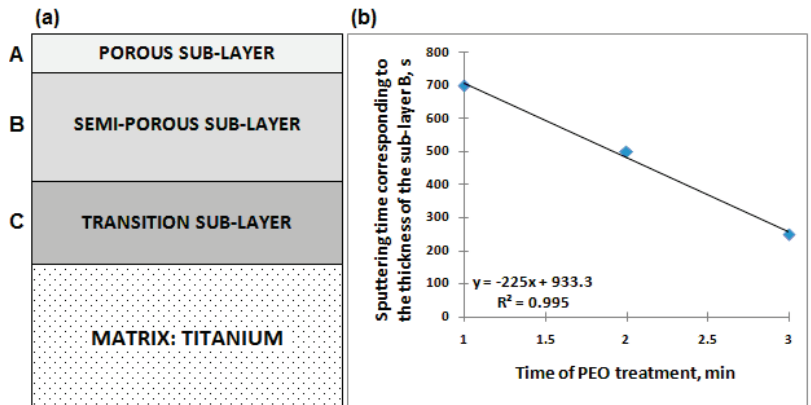

Figure 5 Model (a) describing PEO coatings formed on Titanium with the thicknesses of the sub-layers $A$ and $C$ equalling sputtering times of $100 \mathrm{~s}$ and $450 \mathrm{~s}$, respectively, sputtering time corresponding to the thickness of the sublayer $\mathrm{B}$ as a function of PEO treatment time (b)
Based on results, which were obtained using voltage with sinusoidal pulsation and which are shown in Figs. 14, the new experiments based on three-level statistical plan with using the commercial DC power supply without any pulsation, were performed. For these experiments, three DC voltages, i.e. $450 \mathrm{~V}_{\mathrm{DC}}, 550 \mathrm{~V}_{\mathrm{DC}}$, and $650 \mathrm{~V}_{\mathrm{DC}}$, were chosen. In Fig. 6, the SEM pictures with two magnifications $(500 \times, 5000 \times)$ of coating formed on Titanium after PEO process at voltage of $450 \mathrm{~V}_{\mathrm{DC}}$ after 3 min in $500 \mathrm{~g} / \mathrm{L}$ of $\mathrm{Cu}\left(\mathrm{NO}_{3}\right)_{2} \cdot 3 \mathrm{H}_{2} \mathrm{O}$ in $1 \mathrm{~L} \mathrm{H}_{3} \mathrm{PO}_{4}$ electrolyte, are presented. The obtained surface is porous as it was observed in Fig. 3. Based on seven EDS results the basic statistics were done. For PEO treatment at 450 $\mathrm{V}_{\mathrm{DC}}$ in the obtained coating were found: copper $(9.9 \pm 0.6$ $\mathrm{wt} \%$ | $6.3 \pm 0.4 \mathrm{at} \%)$, phosphorus $(37.3 \pm 0.7 \mathrm{wt} \% \mid 48.9 \pm 0.7$ 
at $\%)$, and titanium $(52.8 \pm 1.0 \mathrm{wt} \% \mid 44.8 \pm 0.9$ at $\%)$. The maxima and minima of copper (max: $10.6 \mathrm{wt} \% \mid 6.8 \mathrm{at} \%$; min: 9 wt $\%$ | 5.8 at\%), phosphorus (max: $37.8 \mathrm{wt} \% \mid 49.4$ at $\%$; min: $35.8 \mathrm{wt} \%$ | $47.3 \mathrm{at} \%$ ), and titanium (max: 54.9 wt $\%$ | 46.8 at $\%$; min: $52.2 \mathrm{wt} \%$ | 44.2 at $\%$ ) show that the results may be classified to the same statistical population. Hence, the decreasing of copper nitrate $\mathrm{Cu}\left(\mathrm{NO}_{3}\right)_{2} \cdot 3 \mathrm{H}_{2} \mathrm{O}$ amounts from $600 \mathrm{~g} / \mathrm{L}$ down to $500 \mathrm{~g} / \mathrm{L}$ in $1000 \mathrm{~mL}$ of concentrated phosphoric acid $\mathrm{H}_{3} \mathrm{PO}_{4}$, and using the stable $\mathrm{DC}$ voltage without pulsation allows to obtain the same chemical composition of PEO coatings under the PEO treatment. In addition, the copper-to-phosphorus ratios were found. They were equal to $0.3 \pm 0.01$ (max: 0.28 ; min: 0.25 ) and $0.13 \pm 0.01$ (max: 0.14 ; min: 0.12 ) by weight and atomic concentrations, respectively.

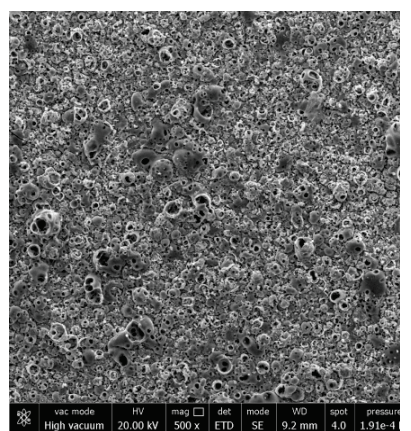

(a)

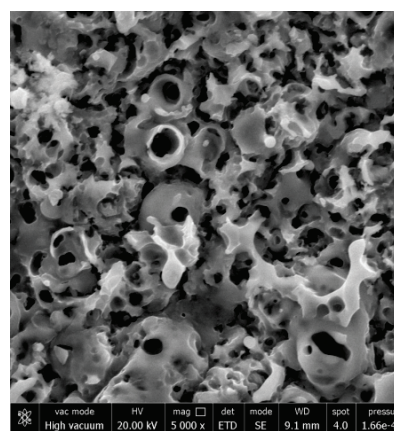

(b)

Figure 6 SEM images of coating formed on Titanium after $\mathrm{PEO}$ process at voltage of $450 \mathrm{VDC}$ after $3 \mathrm{~min}$; in $500 \mathrm{~g} / \mathrm{L}$ of $\mathrm{Cu}\left(\mathrm{NO}_{3}\right)_{2} \cdot 3 \mathrm{H}_{2} \mathrm{O}$ in $\mathrm{H}_{3} \mathrm{PO}_{4}$ electrolyte. Magnifications: $500 \times(\mathrm{a})$ and $5000 \times$ (b)

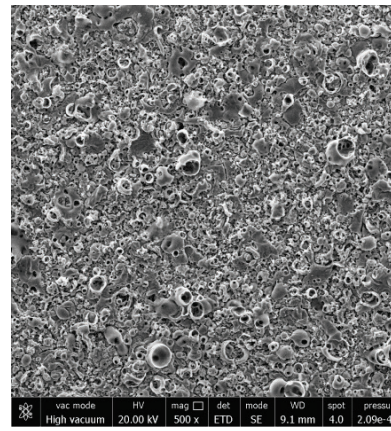

(a)

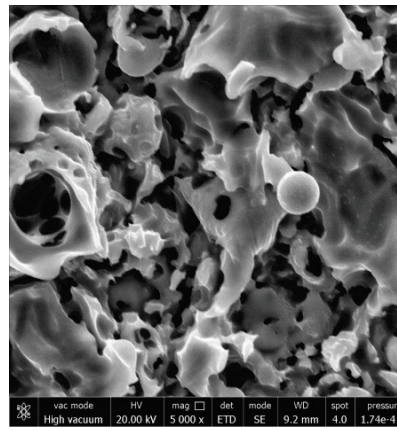

(b)
Figure 7 SEM images of coating formed on Titanium after $\mathrm{PEO}$ process at voltage of $550 \mathrm{VDC}$ after $3 \mathrm{~min}$; in $500 \mathrm{~g} / \mathrm{L}$ of $\mathrm{Cu}\left(\mathrm{NO}_{3}\right)_{2} \cdot 3 \mathrm{H}_{2} \mathrm{O}$ in $\mathrm{H}_{3} \mathrm{PO}_{4}$ electrolyte. Magnifications: $500 \times(a)$ and $5000 \times(b)$

In Fig. 7, the SEM pictures with two magnifications $(500 \times, 5000 \times)$ of coating formed on Titanium after PEO process at voltage of $550 \mathrm{~V}_{\mathrm{DC}}$ after $3 \mathrm{~min}$ in $500 \mathrm{~g} / \mathrm{L}$ of $\mathrm{Cu}\left(\mathrm{NO}_{3}\right)_{2} \cdot 3 \mathrm{H}_{2} \mathrm{O}$ in $1000 \mathrm{~mL} \mathrm{H}_{3} \mathrm{PO}_{4}$ electrolyte, are presented. The obtained surface is porous as it was observed in Fig. 6. For PEO treatment at $550 \mathrm{~V}_{\mathrm{DC}}$ in the obtained coating, copper $(13.4 \pm 0.4 \mathrm{wt} \% \mid 8.6 \pm 0.3 \mathrm{at} \%)$, phosphorus $(38.3 \pm 0.4 \mathrm{wt} \% \mid 50.4 \pm 0.4 \mathrm{at} \%)$, and titanium (48.2 \pm 0.5 wt $\% \mid 41.0 \pm 0.4$ at $\%)$, were detected. The maxima and minima of copper (max: $14.3 \mathrm{wt} \% \mid 9.2 \mathrm{at} \%$; min: $13.1 \mathrm{wt} \%$ | $8.4 \mathrm{at} \%$ ), phosphorus (max: $38.9 \mathrm{wt} \%$ | $51.0 \mathrm{at} \%$; $\min : 37.8 \mathrm{wt} \% \mid 49.8 \mathrm{at} \%$ ), and titanium (max: 48.9 wt $\%$ | 41.6 at $\%$; min: 47.7 wt $\%$ | 40.5 at $\%$ ) show clearly that with PEO treatment at $550 \mathrm{~V}_{\mathrm{DC}}$, the obtained coating contains more copper than that one obtained at $450 \mathrm{~V}_{\mathrm{DC}}$. This trend is also confirmed by copper-tophosphorus ratio, which was equal to $0.35 \pm 0.01$ (max:
0.38; $\min : 0.34$ ) and $0.17 \pm 0.004$ (max: 0.18 ; $\min : 0.17)$ by weight and atomic concentrations, respectively.

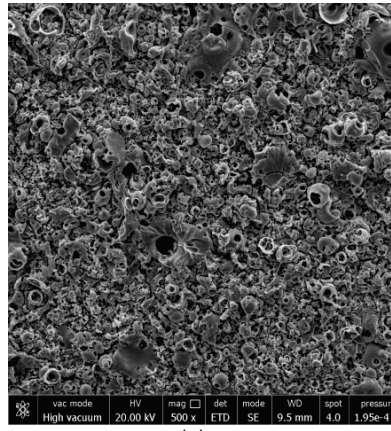

(a)

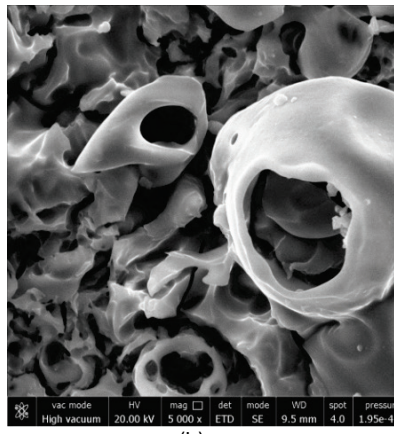

(b)
Figure 8 SEM images of coating formed on Titanium after $\mathrm{PEO}$ process at voltage of $650 \mathrm{VDC}$ after $3 \mathrm{~min}$; in $500 \mathrm{~g} / \mathrm{L}$ of $\mathrm{Cu}\left(\mathrm{NO}_{3}\right)_{2} \cdot 3 \mathrm{H}_{2} \mathrm{O}$ in $\mathrm{H}_{3} \mathrm{PO}_{4}$ electrolyte. Magnifications: $500 \times(\mathrm{a})$ and $5000 \times(\mathrm{b})$

In Fig. 8, the SEM pictures with two magnifications $(500 \times, 5000 \times)$ of porous coating formed on Titanium after PEO process at voltage of $650 \mathrm{~V}_{\mathrm{DC}}$ after $3 \mathrm{~min}$ in $500 \mathrm{~g} / \mathrm{L}$ of $\mathrm{Cu}\left(\mathrm{NO}_{3}\right)_{2} \cdot 3 \mathrm{H}_{2} \mathrm{O}$ in $1 \mathrm{~L} \mathrm{H}_{3} \mathrm{PO}_{4}$ electrolyte, are presented. For PEO treatment at $650 \mathrm{~V}_{\mathrm{DC}}$ in the obtained coating, copper $(12.2 \pm 0.5 \mathrm{wt} \% \quad 7.9 \pm 0.3$ at $\%)$, phosphorus $(35.1 \pm 0.6 \mathrm{wt} \% \mid 46.7 \pm 0.7$ at $\%)$, and titanium $(52.7 \pm 0.8$ wt $\%$ | 45.4 \pm 0.8 at $\%$ ), were found.

The maxima and minima of copper (max: $12.8 \mathrm{wt} \%$ 8.3 at $\%$; min: $11.4 \mathrm{wt} \% \mid 7.4$ at $\%$ ), phosphorus (max: 35.9 wt $\%$ | 47.4 at $\%$; min: 34.2 wt $\%$ | 45.8 at $\%$ ), and titanium (max: $54.0 \mathrm{wt} \%$ | 46.5 at $\%$; min: $51.4 \mathrm{wt} \%$ | 44.1 at $\%$ ) show clearly that with PEO treatment at $650 \mathrm{~V}$, the obtained coating contains more copper than that one obtained at 450 $\mathrm{V}_{\text {DC }}$ (aver. 6.3 at $\%$ ). It is also confirmed by copper-tophosphorus ratios, which were equal to $0.35 \pm 0.01$ (max: 0.37 ; min: 0.33 ) and $0.17 \pm 0.01$ (max: 0.18 ; min: 0.16 ) by weight and atomic concentrations, respectively.

For better characterization of the obtained PEO surfaces, i.e. roughness/porosity, some 2D roughness parameters ( $R a, R z, R z$ ISO, $\left.R q, R t, R S m, l_{0}, D\right)$, as described in the point 2 (Method), were selected. It is clearly visible in Fig. 9 that to distinguish the PEO surfaces obtained with using of different voltages $\left(450 \mathrm{~V}_{\mathrm{DC}}\right.$, $\left.550 \mathrm{~V}_{\mathrm{DC}}, 650 \mathrm{~V}_{\mathrm{DC}}\right), R a, R q, l_{0}$ roughness parameters are the best ones, which may be used to describe the coatings. The interpretation of these parameters should be as follows: the biggest roughness should be identified as surface with opened and big pores, while the small roughness points to the porous surface with small pores or closed ones. The results presented in Fig. 6 show that the voltage of PEO treatment has a significant impact on surface roughness/porosity. For PEO surfaces obtained at $450 \mathrm{~V}$, the $R a, R q, l_{0}$ parameters were equal to $1.36 \pm 0.10 \mu \mathrm{m}$, $1.8 \pm 0.13 \mu \mathrm{m}, 1.0102 \pm 0.0011$, while for $650 \mathrm{~V}$ they were $3.97 \pm 0.19 \mu \mathrm{m}, 5.04 \pm 0.20 \mu \mathrm{m}, 0.8442 \pm 0.003$, respectively.

In Fig. 10, XPS spectra of coating formed on titanium after $\mathrm{PEO}$ process at voltages of $450 \mathrm{~V}_{\mathrm{DC}}$ and $650 \mathrm{~V}_{\mathrm{DC}}$ after $3 \mathrm{~min}$ in $500 \mathrm{~g} / \mathrm{L}$ of $\mathrm{Cu}\left(\mathrm{NO}_{3}\right)_{2} \cdot 3 \mathrm{H}_{2} \mathrm{O}$ in $1 \mathrm{~L}_{3} \mathrm{PO}_{4}$ electrolyte, are presented. The results clearly show that in the upper layer $(10 \mathrm{~nm})$ there are titanium $\left(\mathrm{Ti}^{4+}\right)$, copper $\left(\mathrm{Cu}^{2+}\right.$ and $\left.\mathrm{Cu}^{+}\right)$as well as phosphorus and oxygen mostly as $\mathrm{PO}_{4}{ }^{3-}$ present, what is confirmed by the binding energies, i.e. $\mathrm{Ti} 2 \mathrm{p}_{3 / 2}(460.2 \mathrm{eV}), \mathrm{Cu} 2 \mathrm{p}(92.8 \mathrm{eV} 935.8 \mathrm{eV}, 942.3 \mathrm{eV}$, $944.6 \mathrm{eV}), \mathrm{P} 2 \mathrm{p}(134 \mathrm{eV}), \mathrm{O} 1 \mathrm{~s}(531.5 \mathrm{eV})$. It may suggest 
that the obtained coating may be considered as a hydroxyapatite-like structure, in which in places where normally are $\mathrm{Ca}^{2+}$ and $\mathrm{OH}^{-}$, here most likely are $\mathrm{Cu}^{2+}$ and
$\mathrm{Cu}^{+}$(the signal of $\mathrm{Cu} 2 \mathrm{p}$ was noised and the analysis was performed based on maximum peaks).
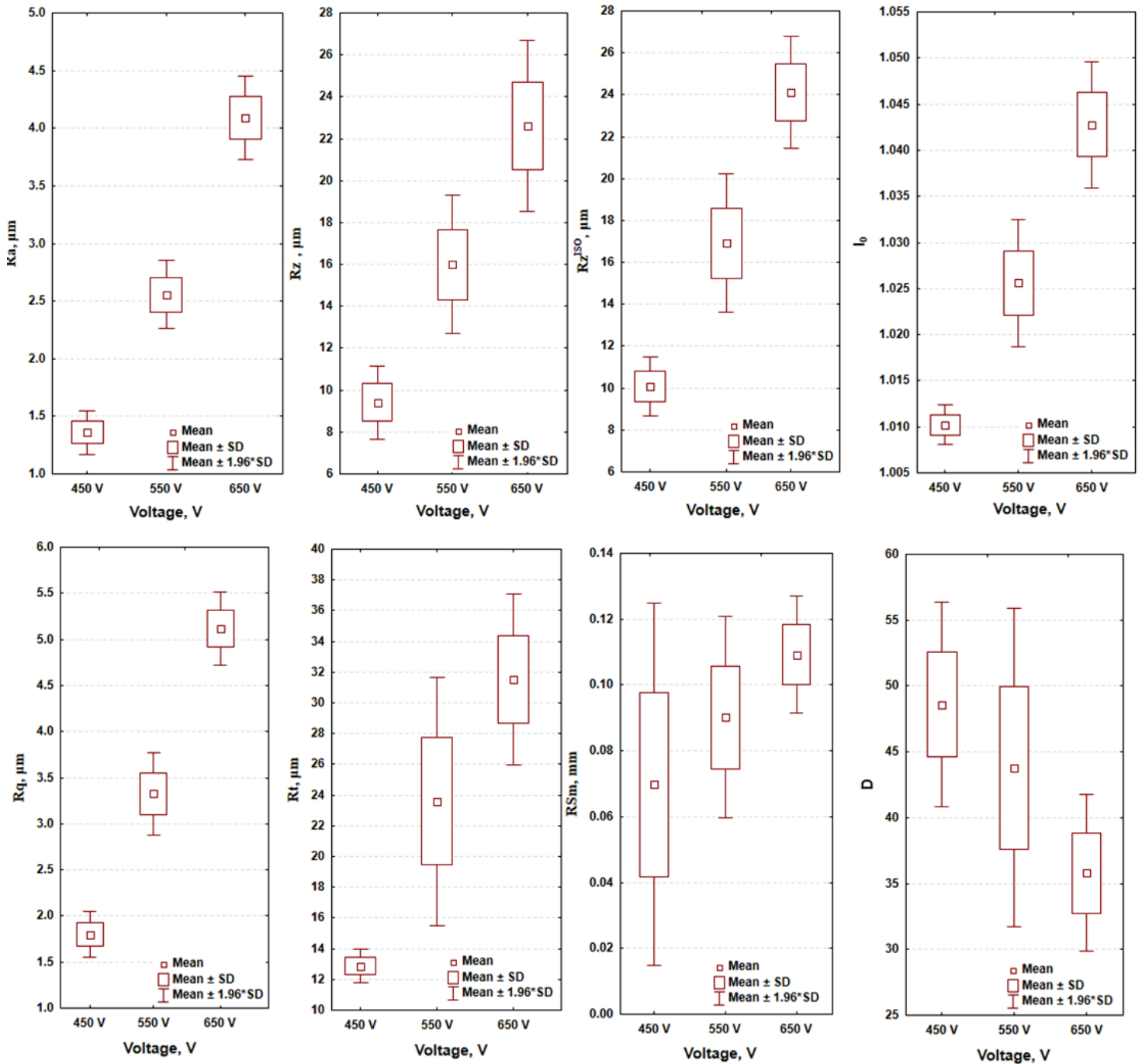

Figure 9 Roughness parameters of coatings formed on Titanium after PEO process at voltages of $450 V_{D C}, 550 \mathrm{VDC}$ and $650 V_{D C}$ after $3 \mathrm{~min}$ in $500 \mathrm{~g} / \mathrm{L}$ of $\mathrm{Cu}\left(\mathrm{NO}_{3}\right)_{2} \cdot 3 \mathrm{H}_{2} \mathrm{O}$ in $1 \mathrm{~L} \mathrm{H}_{3} \mathrm{PO}_{4}$ electrolyte
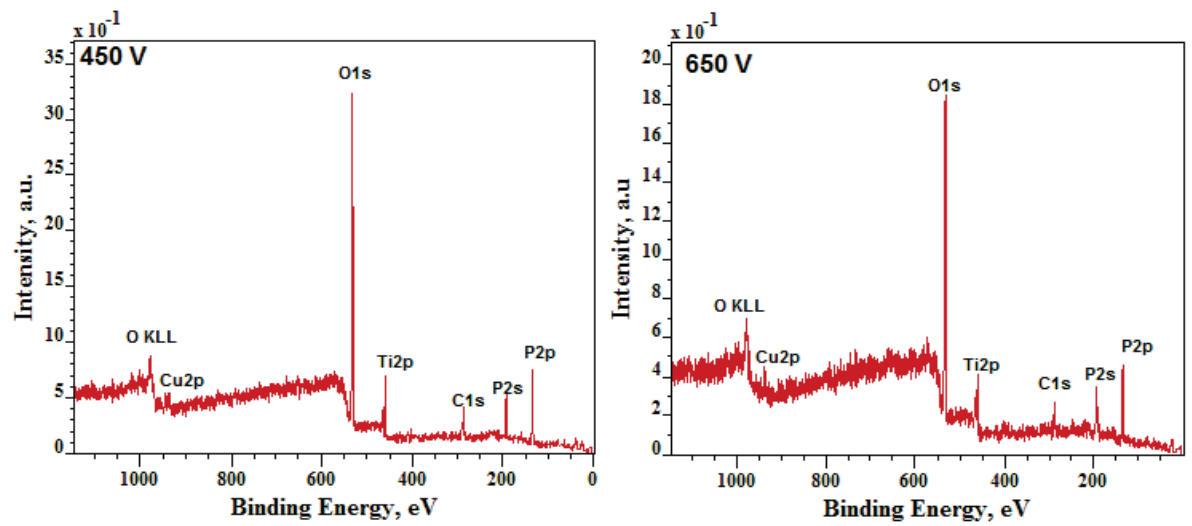

Figure 10 XPS spectra of coating obtained on titanium at voltages of $450 \mathrm{~V}_{D C}$ and $650 \mathrm{VDC}$ after 3 min treatment in $500 \mathrm{~g} / \mathrm{L} \mathrm{of} \mathrm{Cu}\left(\mathrm{NO}_{3}\right)_{2} \cdot 3 \mathrm{H}_{2} \mathrm{O}$ in $1 \mathrm{~L} \mathrm{H} \mathrm{H}_{3} \mathrm{PO}$ electrolyte.

\section{CONCLUSIONS}

Performed complex characterization of the phenomena of electrolyte aging and influence of PEO processing time on creation of porous coatings enriched with copper on the
CP Titanium Grade 2 resulted in developing the series of conclusions:

- Time of process surely has an influence on the chemical composition and thickness of the obtained porous coatings. 
- The longer time of PEO treatment, the thinner is the porous coating and the lower amounts of copper, phosphorus and oxygen are detected inside it.

- $\quad$ The top sub-layers ("A" in Fig. 5a), having a thickness corresponding with the sputtering time equaling $100 \mathrm{~s}$ are very porous and contaminated by organic substances down to about $50 \mathrm{~s}$ by sputtering time, because of the contact with surrounding air and with cleaning liquids (alcohols).

- The thickness of semi-porous sub-layer ("B" in Fig. $5 b)$ depends on the treatment time; the thickest sublayer appears to be after one-minute PEO treatment and it decreases with increasing time of processing.

- The thickness of semi-porous sub-layer ("B" in Fig. 5c) also depends on electrolyte aging: the thickest coating is obtained after first PEO treatment; after each successive PEO treatment, the coating thickness decreases.

- The transition sub-layers ("C" in Fig. 5a) have thickness corresponding with a sputtering time equaling $450 \mathrm{~s}$; for the third sample successively treated during three minutes of oxidation, only two sub-layers, namely "A" and "C", are present.

- The PEO potential has an impact on the roughness/porosity of the PEO coatings: the higher is the potential, the bigger are the roughnesses, i.e. the obtained pores are opened and/or have bigger diameters; the lower is the potential, the smaller are the roughnesses, i.e. the obtained pores are closed and/or have small diameters.

- In all likelihood the upper layer of $10 \mathrm{~nm}$ of described coatings is constructed of titanium $\left(\mathrm{Ti}^{4+}\right)$, copper $\left(\mathrm{Cu}^{2+}\right.$ and $\left.\mathrm{Cu}^{+}\right)$, and phosphates $\left(\mathrm{PO}_{4}{ }^{3-}\right)$.

\section{Acknowledgements}

This work was supported by a subsidy from Grant OPUS 11 of National Science Centre, Poland, with registration number 2016/21/B/ST8/01952, titled "Development of models of new porous coatings obtained on titanium by Plasma Electrolytic Oxidation in electrolytes containing phosphoric acid with addition of calcium, magnesium, copper and zinc nitrates".

Many thanks are directed to Professor Czesław Łukianowicz, DSc PhD, head of Metrology and Quality Division, former Dean of the Faculty of Mechanical Engineering of KUT, for making available a computerized HOM-MELTESTER T800 system of Hommelwerke $\mathrm{GmbH}$.

\section{REFERENCES}

[1] Lochynski, P., Sikora, A., \& Szczygieł, B. (2017). Surface morphology and passive film composition after pickling and electropolishing. Surface Engineering, 33, 395-403. https://doi.org/10.1080/02670844.2016.1238189

[2] Lochynski, P., Kowalski, M., Szczygieł, B., \& Kuczewski, K. (2016). Improvement of the stainless steel electropolishing process by organic additives. Polish Journal of Chemical Technology, 18(4), 76-81. https://doi.org/10.1515/pjct-2016-0074

[3] Hryniewicz, T., Konarski, P., Rokosz, K., \& Rokicki, R. (2011). SIMS analysis of hydrogen content in near surface layers of AISI 316L SS after electrolytic polishing under different conditions. Surface \& Coatings Technology, 205(17-18), 4228-4236.

https://doi.org/10.1016/j.surfcoat.2011.03.024

[4] Rokosz, K., Simon, F., Hryniewicz, T., \& Rzadkiewicz, S. (2015). Comparative XPS analysis of passive layers composition formed on AISI 304 L SS after standard and high-current density electropolishing. Surface and Interface Analysis, 47(1), 87-92. https://doi.org/10.1002/sia.5676

[5] Hryniewicz, T., Rokosz, K., \& Zschommler Sandim, H. R. (2012). SEM/EDX and XPS studies of niobium after electropolishing. Applied Surface Science, 263, 357-361. https://doi.org/10.1016/j.apsusc.2012.09.060

[6] Rokosz, K. \& Hryniewicz, T. (2012). Characterization of Passive Film Formed on AISI 316L Stainless Steel after Magnetoelectropolishing in a Broad Range of Polarization Parameters. Steel Research International, 83(9), 910-918. https://doi.org/10.1002/srin.201200046

[7] Hryniewicz, T., Rokicki, R., \& Rokosz, K. (2012). Co-Cr alloy corrosion behaviour after electropolishing and "magnetoelectropolishing" treatments. Materials Letters, 62(17-18), 910-918.

[8] Hryniewicz, T. \& Rokosz, K. (2014). Corrosion resistance of magnetoelectropolished AISI 316L SS biomaterial. AntiCorrosion Methods and Materials, 61(2), 57-64. https://doi.org/10.1108/ACMM-03-2013-1249

[9] Rokosz, K., Hryniewicz, T., \& Raaen, S. (2014). Cr/Fe ratio by XPS spectra of magnetoelectropolished AISI 316L SS fitted by gaussian-lorentzian shape lines. Tehnicki vjesnik, 21(3), 533-538.

[10] Rokosz, K. \& Hryniewicz, T. (2013). XPS measurements of LDX 2101 duplex steel surface after magnetoelectropolishing. International Journal of Materials Research, 104(2), 1223-1232. https://doi.org/10.3139/146.110984

[11] Rokicki, R., Hryniewicz, T., Pulletikurthi, C., Rokosz, K., \& Munroe, N. (2015). Towards a Better Corrosion Resistance and Biocompatibility Improvement of Nitinol Medical Devices. Journal of Materials Engineering and Performance, 24(4), 1634-1640. https://doi.org/10.1007/s11665-015-1429-x

[12] Hryniewicz, T., Rokosz, K., Rokicki, R., \& Prima, F. (2015). Nanoindentation and XPS Studies of Titanium TNZ Alloy after Electrochemical Polishing in a Magnetic Field. Materials, 8(1), 205-215. https://doi.org/10.3390/ma8010205

[13] Rokosz, K., Lahtinen, J., Hryniewicz, T., \& Rzadkiewicz, S. (2015). XPS depth profiling analysis of passive surface layers formed on austenitic AISI 304L and AISI 316L SS after high-current-density electropolishing. Surface \& Coatings Technology, 276, 516-520. https://doi.org/10.1016/j.surfcoat.2015.06.022

[14] Rokosz, K., Hryniewicz, T., Rzadkiewicz, S., \& Raaen, S. (2015). High-Current-Density Electropolishing (HDEP) of AISI 316L (EN 1.4404) stainless steel. Tehnicki vjesnik, 22(2), 415-424. https://doi.org/10.17559/TV-20140722110711

[15] Rokosz, K., Hryniewicz, T., Simon, F., \& Rzadkiewicz, S. (2016). Comparative XPS analyses of passive layers composition formed on duplex 2205 SS after standard and high-current-density electropolishing. Tehnicki vjesnik, 23(3), 731-735. https://doi.org/10.17559/TV-20141107094438

[16] Rokosz, K., Hryniewicz, T., \& Raaen, S. (2017). XPS analysis of nanolayer formed on AISI 304L SS after HighVoltage Electropolishing (HVEP). Tehnicki vjesnik, 24(Suppl. 2), 321-326. https://doi.org/10.17559/TV-20151125085632

[17] Rokosz, K., Hryniewicz, T., Raaen, S., \& Malorny, W. (2017). Fabrication and characterisation of porous coatings obtained by Plasma Electrolytic Oxidation. Journal of Mechanical and Energy Engineering, 1(1), 23-30. 
[18] Hempel, F., Finke, B., Zietz, C., Bader, R., Weltmann, K.-D. M., \& Polak, M. (2014). Antimicrobial surface modification of titanium substrates by means of plasma immersion ion implantation and deposition of copper. Surface \& Coatings Technology, 256, 52-58. https://doi.org/10.1016/j.surfcoat.2014.01.027

[19] Rokosz, K., Hryniewicz, T., Dudek, L., Matysek, D., Valicek, J., \& Harnicarova, M. (2016). SEM and EDS analysis of surface layer formed on titanium after plasma electrolytic oxidation in $\mathrm{H}_{3} \mathrm{PO}_{4}$ with the addition of $\mathrm{Cu}\left(\mathrm{NO}_{3}\right)_{2}$. Journal of Nanoscience and Nanotechnology, 16(8), 7814-7817. https://doi.org/10.1166/jnn.2016.12558

[20] Sowa, M., Worek, J., Dercz, G., Korotin, D. M., Kukharenko, A. I., Kurmaev, E. Z., Cholakh, S. O., Basiaga, M., \& Simka, W. (2016). Surface characterisation and corrosion behaviour of niobium treated in a $\mathrm{Ca}$ - and $\mathrm{P}$ containing solution under sparking conditions. Electrochimica Acta, 198, 91-103. https://doi.org/10.1016/j.electacta.2016.03.069

[21] Sowa, M., Kazek-Kęsik, A., Socha, R. P., Dercz, G., Michalska, J., \& Simka, W. (2013). Modification of tantalum surface via plasma electrolytic oxidation in silicate solutions. Electrochimica Acta, 114, 627-636. https://doi.org/10.1016/j.electacta.2013.10.047

[22] Rokosz, K., Hryniewicz, T., Chapon, P., Raaen, S., \& Zschommler Sandim, H. R. (2016). XPS and GDOES Characterization of Porous Coating Enriched with Copper and Calcium Obtained on Tantalum via Plasma Electrolytic Oxidation. Journal of Spectroscopy, 2016(7093071), 1-7. https://doi.org/10.1155/2016/7093071

[23] Simka, W., Sowa, M. M, Socha, R. P., Maciej, A., \& Michalska, J. (2013). Anodic oxidation of zirconium in silicate solutions. Electrochimica Acta, 104, 518-525. https://doi.org/10.1016/j.electacta.2012.10.130

[24] Rokosz, K., Hryniewicz, T., \& Raaen, S. (2016). Development of plasma electrolytic oxidation for improved Ti6Al4V biomaterial surface properties. International Journal of Advanced Manufacturing Technology, 85(9-12), 2425-2437. https://doi.org/10.1007/s00170-015-8086-y

[25] Rokosz, K., Hryniewicz, T., \& Raaen, S. (2017). SEM, EDS and XPS analysis of nanostructured coating formed on NiTi biomaterial alloy by Plasma Electrolytic Oxidation (PEO). Tehnicki vjesnik, 24(1), 193-198. https://doi.org/10.17559/TV-20151021112657

[26] Rokosz, K., Hryniewicz, T., Raaen, S., Chapon, P., \& Prima, F. (2017). Development of copper-enriched porous coatings on ternary $\mathrm{Ti}-\mathrm{Nb}-\mathrm{Zr}$ alloy by plasma electrolytic oxidation. International Journal of Advanced Manufacturing Technology, 89(9-12), 2953-2965. https://doi.org/10.1007/s00170-016-9206-z

[27] Rokosz, K, Hryniewicz, T., Raaen, S., \& Chapon, P. (2016). Investigation of porous coatings obtained on $\mathrm{Ti}-\mathrm{Nb}-\mathrm{Zr}-\mathrm{Sn}$ alloy biomaterial by plasma electrolytic oxidation: characterisation and modelling. International Journal of Advanced Manufacturing Technology, 87(9-12), 3497-3512. https://doi.org/10.1007/s00170-016-8692-3

[28] Yu, S., Yu, Z., Wang, G., Han, J., Ma, X. \& Dargusch M. S. (2011). Preparation and osteoinduction of active micro-arc oxidation films on Ti-3Zr-2Sn-3Mo-25Nb alloy. Trans. Nenferrous Met. Soc. China, 21, 573-580. https://doi.org/10.1016/S1003-6326(11)60753-X

[29] Yao, X., Xiangyu, Z., Haibo, W., Tian, L., Ma, Y., \& Tang, B. (2014). Microstructure and antibacterial properties of $\mathrm{Cu}-$ doped $\mathrm{TiO}_{2}$ coating on titanium by micro-arc oxidation. Applied Surface Science, 292, 944-947. https://doi.org/10.1016/j.apsusc.2013.12.083

[30] Rokosz, K., Hryniewicz, T., Raaen, S., Chapon, P., \& Dudek, Ł. (2017). GDOES, XPS, and SEM with EDS analysis of porous coatings obtained on titanium after plasma electrolytic oxidation. Surface and Interface Analysis, 49(4), 303-315. https://doi.org/10.1002/sia.6136

[31] Rokosz, K., Hryniewicz, T., Matysek, D., Raaen, S., Valicek, J., Dudek, Ł., \& Harničarova, M. (2016). SEM, EDS and XPS Analysis of the Coatings Obtained on Titanium after Plasma Electrolytic Oxidation in Electrolytes Containing Copper Nitrate. Materials, 9(5), 1-12. https://doi.org/10.3390/ma9050318

[32] Rokosz, K., Hryniewicz, T., Gaiaschi, S., Chapon, P., Raaen, S., Pietrzak, K., \& Malorny, W. (2017). Characterisation of Calcium- and Phosphorus-Enriched Porous Coatings on CP Titanium Grade 2 Fabricated by Plasma Electrolytic Oxidation. Metals, 7(9), 1-17. https://doi.org/10.3390/met7090354

[33] Kusnerova, M., Valiček, J., Harničarova, M., Hryniewicz, T., Rokosz, K., Palkova, Z., Vaclavik, V., Repka, M., \& Bendova, M. (2013). A Proposal for Simplifying the Method of Evaluation of Uncertainties in Measurement Results. Measurement Science Review, 13(1), 1-6. https://doi.org/10.2478/msr-2013-0007

[34] Valiček, J., Drzik, M.M., Hryniewicz, T., Harničarova, M., Rokosz, K., Kusnerova, M., Barcova, K., \& Brazina, D. (2012). Non-Contact Method for Surface Roughness Measurement after Machining. Measurement Science Review, 12(5), 184-188. https://doi.org/10.2478/v10048-012-0028-3

\section{Contact information:}

Krzysztof ROKOSZ, DSc PhD, Assoc. Prof.

Division of BioEngineering and Surface Electrochemistry Koszalin University of Technology

Racławicka 15-17, 75-620 Koszalin, Poland

E-mail: rokosz@tu.koszalin.pl

Tadeusz HRYNIEWICZ, DSc PhD ME CE, Professor (corresponding author)

Division of BioEngineering and Surface Electrochemistry

Koszalin University of Technology

Racławicka 15-17, PL 75-620 Koszalin, Poland

E-mail: Tadeusz.Hryniewicz@tu.koszalin.pl

Sofia GAIASCHI, PhD

HORIBA Jobin Yvon S.A.S.,

16-18, rue du Canal- 91165 Longjumeau cedex, France

E-mail: sofia.gaiaschi@horiba.com

Patrick CHAPON, PhD

HORIBA Jobin Yvon S.A.S.,

16-18, rue du Canal- 91165 Longjumeau cedex, France

E-mail: patrick.chapon@horiba.com

Steinar RAAEN, PhD

Department of Physics

Norwegian University of Science and Technology (NTNU)

Realfagbygget E3-124 Høgskoleringen 5, NO 7491 Trondheim

E-mail: steinar.raaen@ntnu.no

\section{Łukasz DUDEK, PhD}

Division of BioEngineering and Surface Electrochemistry

Koszalin University of Technology

Racławicka 15-17, 75-620 Koszalin, Poland

E-mail: lukasz.dudek@tu.koszalin.pl

Winfried MALORNY, PhD

Hochschule Wismar-University of Applied Sciences Technology, Business and Design, Faculty of Engineering, DE 23966 Wismar, Germany

E-mail: winfried.malorny@hs-wismar.de 